\title{
Research on Transformation Development Path of the Private Undergraduate College
}

\author{
Zhaoyang Yuan ${ }^{1, a}$ \\ ${ }^{1}$ Xi'an International University, Xi'an, Shaanxi Province, 710077 \\ hunter2011@foxmail.com
}

Keywords: Private Undergraduate College, Transformation Development, Path

\begin{abstract}
As an important part of local regular undergraduate institutions, private universities have played an important role in the service of local economic and social development and training of highly qualified technical personnel. Currently, the country accelerates the deployment of modern vocational education system, guide the transformation and development of a number of regular undergraduate colleges and universities. The private colleges and universities should explore strategic development path which in line with the actual situation of school and realize the real connotation development and leapfrog development. This paper detailed the theory exploration and practice innovation of school running mode, school-enterprise cooperation, talent training mode, personnel system in the school transformation development in order to provide reference for transformation development of other private undergraduate college.
\end{abstract}

\section{Introduction}

There are over 30 years of history of private undergraduate college in China and they have made important contributions to the promotion of employment and social development. But we must note that the current private higher education cannot fully meet the needs of economic and social development, discipline structure is not quite reasonable, the school quality to be improved and the school conditions to be improved. Currently, the country has made a major strategic plan to guide the restructuring and development of a number of regular undergraduate institutions, private colleges and universities for further implementation of innovation-driven development strategy, speed up transformation mode, adjusting structure, promoting the role of a very important upgrade [1].

\section{The Transformation Development of Private Undergraduate College}

It is needed to service the national strategic plan of the vocational education development. The local universities transformation and development which take private universities as an important force, not only economic development pattern, industrial restructuring and upgrading of the urgent requirements, but also to accelerate the comprehensive reform of education, innovation and development of higher education classification and management, improve the modern vocational education system urgent needs, but also to promote the local industrial restructuring and upgrading, as well as solve the "labor shortage" and "Employment" structural unemployment only way. Currently, from the national government to the national leadership level, from schools to business trade associations, it has for the restructuring and development of private universities in the formation of a broad consensus and creates a better environment. Overall, accelerate the restructuring and development of Private Universities in line with the "three needs": meet the needs of reform, economic and social reform in Private Universities Forced to speed up transformation and development; meet the needs of the market, the employer needs of the market Forced Private Universities accelerate restructuring and development; the need to meet the education, not suited to the development of education Private Universities Forced to speed up transformation and development [2].

It is needed to construct Chinese private undergraduate college with high level. The development roads of Private Universities are not in the same starting line with public universities in 
the relatively large levels, it is in a special environment to find their foothold and targeting. Under most private colleges and universities located in the "application type., And has a social financing, independent schools, focus on quality, streamlining the organization, staff efficient, flexible, innovative ideas and other school characteristics. At the national guide and encourage restructuring and development of Local Colleges in the New Situation, private colleges to make full use of their own advantages, so the school to better reflect regional characteristics, personnel training more responsive to regional economic and social development, scientific research more closely integrated regional industrial restructuring and upgrading requirements, operating efficiency to meet the aspirations of the government and the public , training quality personnel to better meet the social development and student employment. Private Universities only constantly updated educational philosophy, improving education levels and improve the governance structure in order to achieve early completion of China's high level of private universities better vision.

\section{The Main Difficulties of the Transformation Development of Private Undergraduate College}

The thinking and educational concept need to change urgently. Compared with ordinary colleges graduate, graduates of vocational schools have not been given due attention and respect society. Part of the private universities by the "cold vocational education, general education fever" phenomenon of influence, there is no clear understanding of the university take the academic road is not feasible, the application of technology type of university development is the way the school.

There are no obvious features of disciplines setting. Part of Private Universities running local, regional characteristics is not obvious, the common pursuit of a professional set of "large considering professional integration not by much, but also not well adapted to the local industrial restructuring and upgrading.

The curriculum system reform is not enough. There is a "put emphasis on theory and contempt practice" issue. Most courses in Private Universities and demand cannot be a good match, "the theory and practice of light," the problem is more prominent, and the traditional "academic" curriculum system discrimination is not obvious.

The ability of servicing local economic and social development of scientific research is not strong. There is a "heavy science, light technical" problem. The total expenditure in 2012, research funding from the new colleges enterprises accounted for only $29.87 \%$ of its total research funding, the total amount of school funding enterprises have received less than 3 million RMB, while private colleges and universities to get funding for enterprises less.

Teachers' professional practice ability is not strong. On the teaching staff, private undergraduate colleges and universities usually focus on academic qualifications, heavy theoretical level, while ignoring the teachers will be converted to the theory of technology, technology transfer real productivity of professional practice. From the surveys, Chinese Academy of Education, the proportion of the majority of school "double type" structure of teachers of less than $30 \%$.

The deep school-enterprise cooperation is difficult and the long-term collaborative innovation operation mechanism has not yet been formed. On the one hand due to the overall strength of Private Universities research is relatively weak, applied scientific research strength is not strong, and the ability to serve local enterprise also inadequate; on the other hand the Government's lack of cooperation between schools and enterprises joint training of skilled high-tech quality and technical personnel of the state system incentive policies. Enterprises to participate in the Higher Education enthusiasm is not high, schools and businesses signed a cooperation framework agreement more, but not more substantive cooperation, many also stay on the surface, the prevalence of " hot school and cold enterprise " phenomenon [3].

\section{The Strategic Path Choice of Transformation Development of Private Undergraduate College}

Promote school transformation and development is both new opportunity and also new challenges for private undergraduate colleges and universities. Under the new situation, private undergraduate 
colleges and universities should seize this opportunity to further emancipate the mind, bold reform and innovation, adhere to open schools, to develop practical and effective measures, in the school system and mechanism, discipline construction, talent training mode, teaching staff, teaching and management service model to further deepen the reform, restructuring and development early realization.

Based on the needs of local development. Based on local development needs requires private Universities deepen education reform, optimize the discipline structure, in terms of professional settings and disciplines in a targeted manner to strengthen the local economic and social development-related content, Curriculum setting the strategic adjustment of local economic and social development in accordance with, the establishment of mechanisms for dynamic teaching programs. Based on local development needs, but also requires private undergraduate colleges and universities to use their educational resources, all kinds of talent through the cultivation area of social development, transformation of scientific research, promote research cooperation and other means of transportation personnel for local economic development. Development based on local needs, but also require a combination of private Universities docking own development reality of local economic and social development of the school, the results of scientific research projects and professional and technical personnel of the invention the school to the community and businesses in a timely manner, so that scientific and technological achievements can quickly be converted to practical productive forces, science and technology innovation to improve the local level, to promote scientific and technological achievements, to provide scientific and technical support for local economic development [4].

Achieve a unique dislocation development. Private Universities in the process of restructuring and development in conjunction with the actual school, pinpoint their location, to create its own characteristics and brand, with characteristic school, it features strong school, special win, the implementation of dislocation development, adhere to the discipline construction process the "first to be after something" strategy and ideas. Public universities are generally strong, with obvious advantages in scientific and technological innovation capability and schooling strength aspect, therefore private undergraduate colleges and universities to establish different from the old research-based training objectives Academic public undergraduate institutions, according to the social needs and their own advantage scientific orientation, the vocational and technical education and into the bachelor's degree in education, cultivate both theoretical basis but also has a strong practical ability and innovative spirit of practical, compound talents, in order to achieve with the traditional type of teaching or educational research public universities The elite training objectives "dislocation." In addition, private undergraduate colleges and universities also adhere to the "Dos and Don'ts" strategy and thinking, blank areas may not want to do and vocational colleges in public universities cannot do to determine its own unique training objectives and personnel training specifications, culture has a strong vocational adaptability and employability and competitiveness of talent.

Construct a professional system that compatible with industrial development. Strategic emerging industries are knowledge-intensive industries, knowledge of the condition is highly sensitive, there is a strong dependence of human resources, requires colleges and universities to train with a clear thinking, independent analysis and creative talents, but also requires talent objectively It has a good educational background and knowledge reserves. In recent years, the national industrial policy, driven by the number and size of the strategic emerging industries continue to expand. This facilitates the restructuring and reform of professional structure from the outside, and the reform of the professional structure in turn promote the development and optimization of industrial structure. Lies in the balance between supply and demand of labor market regulation law, requires private undergraduate colleges and universities to the market as the orientation, adjust the settings on the professional objective, and to make the necessary talent needs assessment at the professional setting, identify itself with strategic the entry point for emerging industries, the full integration of existing courses condition, build school brand specialty [5]. 
Make the innovation of the application talents training mode. In the transition development process, the Private Universities should continue to optimize the training program to support research cooperation platform, innovation application talents training mode, to explore new ways of personnel training. First, schools and businesses jointly develop personnel training programs. Schools set up professional guidance committee composed of professors and business people, who want to actively participate in providing a venue for the enterprise, the introduction of preferential policies to attract enterprises to school. Third, we must establish school-enterprise partnerships. Establish school-enterprise cooperation programs and collaborative training mechanism, schools and businesses to explore mutual build training base, try to lead the school into the plant, cooperation in the form of lead plant into the school, the former shop and other school-enterprise integration of school, so that students experience in the business line a wealth of technical personnel under the guidance involved in the production or technical programs to develop students' practical abilities. Finally, you can fully rely on Vocational Education Group platform to strengthen the depth of cooperation with the members of the unit, a "build a win-win situation, common share, condominium co-education" of personnel training system, to achieve three-dimensional people total fertility school system, promoting private undergraduate colleges and universities to use the rapid transformation of the Technical University.

\section{Conclusion}

Many private colleges and universities have taken a solid pace in transformation and development, but the transformation and development is not easy and there are still many problems and difficulties in the implementation process. For example, in the current social environment, the cooperation power between of enterprise and school is generally insufficient, enthusiasm is not high and these are not conducive for school to form system planning and design from all aspects such as orientation, discipline construction, talent training, industry-university cooperation and social services. Thus, private undergraduate colleges should continue with exploration, reform and innovation combining with their actual situation, ultimately form a virtuous circle mechanism with school characteristics and sustainable development and achieve the goal of completing the high level well-known private universities.

\section{Acknowledgements}

This paper belongs to the Shaanxi Province Chinese Vocational Education Association 2015 Vocational Education Issues (ZDKT201505 )

\section{References}

[1] R.X. Zeng, Local Universities restructuring and development practice and policy research report, J. Tianjin Vocational and Technical Normal College, 5(2007) 46-47.

[2] C.Li, Reflections on the construction of experiment teaching demonstration center of new private undergraduate colleges, J. Shandong Foreign Language Teaching. 11(2006) 26-30.

[3] C.Y.Wang, How to raise the confidence of private undergraduate students, J. Vocational and Technical Education. 9 (2011) 56-58.

[4] J.X.Li, Transformation development of local universities: path selection and connotation construction, J. Vocational and Technical Education .9(2009) 19-22.

[5] Y.X.Zhang, Cooperative condition and performance evaluation of local colleges, J. Shaoxing University. 4(2007) 129-132. 